Acta medico-historica Rigensia (1992) I: 329-330

DOI: 10.25143/amhr.1992.I.27

\title{
ВИКТОР КАЛНИН
}

Историки медицины Прибалтики понесли тяжелую утрату. 22 марта 1992 г. на 63-м году жизни скончался крупнейший эстонский историк медицины Виктор Калнин.

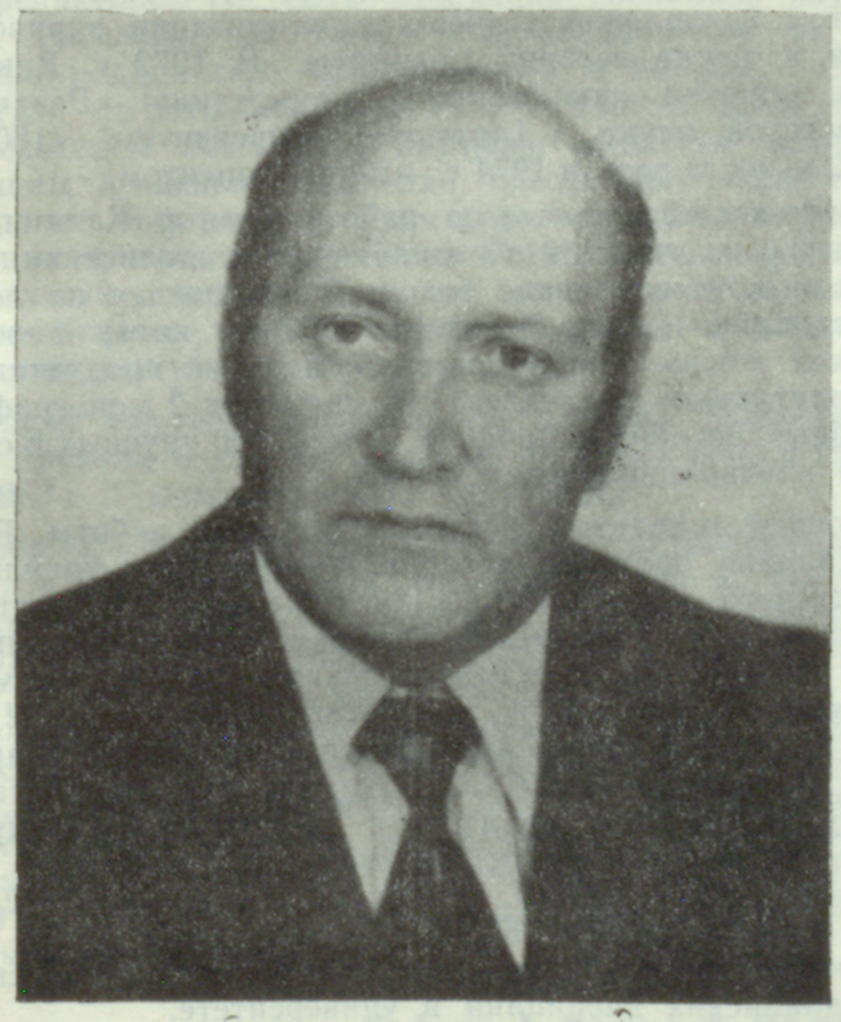

Своим неутомимым исследовательским трудом он получил известность как на своей родине в Әстонии, так и за рубежом, особенно в качестве лучшего знатока истории 
Тартуского (Дерптского, Юрьевского) центра высшего медицинского образования и медицинской науки.

Виктор Калнин родился 21 августа 1929 г. в г. Синди Пярнуского уезда в семье рабочего. Его предки происходят из Латвии. Посещал Печерскую гимназию и Вырускую среднюю школу, а в 1954 г. с отличием окончил медицинский факультет Тартуского государственного университета. Остался на преподавательской работе в университете при кафедре гигиены и организации здравоохранения, которую (с небольшим перерывом в 1979-1981 гг.) выполнял до конца жизни. Преподавал курс общей гигиены, потом социальной гигиены и организации здравоохранения, а также истории медицины. В 1972 г. Виктор Калнин защитил кандидатскую диссертащию «Развитие гигиенической науки в Тартуском университете (18021917 гг.) », после чего в 1974 г. избран доцентом.

Научно-исследовательскую работу Виктор Калнин начал с изучения гигиены водоснабжения и статистики долголетия в Эстонии, однако вскоре переключился на историю медицины и здравоохранения Эстонии, которой посвятил свою жизнь. Свидетельством научной продуктивности талантливого исследователя являются 2 монографии, 12 учебных пособий и брошюр, свыше 300 научных и свыше 650 научно-популярных статей.

Основной тематикой исследовательской работы Виктора Калнина являлась история медицинского факультета Тартуского университета. Им написаны соответстующие главы для монографии «История Тартуского университета. 1632-1982» (трехтомное издание на эстонском и однотомное на русском и английском языках в 1982 г.), за что в 1985 г. в группе авторов он удостоен Государственной премии Эстонской ССР. Другая крупная работа по данному разделу - монография «Медицинский факультет Тартусккого государственного университета» (на эстонском языке в 1976 г. и на русском языке в 1982 г.). Кроме того, Виктором Қалнином выполнены также обстоятельные исследования по развитию почти всех основных медицинских дисциплин в университете.

Весьма важное место в своей исследовательской работе Виктор Калнин посвятил выяснению роли научных контактов между медицинским факультетом Тартуского университета и другими медицинскими высшими учебны- 
ми заведениями как в России (б. СССР), так и на Западе. Значительная часть этих исследований выполнена в соавторстве с другими коллегами из Риги, Каунаса, Вильнюса, Ленинграда, Москвы, Одессы, Харькова, Гродно и др.

По приглашению П. Страдыня, начиная с 1958 г. Виктор Калнин являлся постоянным участником, а потом также организатором традиционных прибалтийских конференций по истории науки, а с 1975 г. - ежегодных научных сессий по истории Тартуского университета; он был редактором 15 соответствующих сборников научных работ. Регулярно он также участвовал почти во всех историко-медицинских мероприятия в бывшем СССР, а иногда - в заграничных. С 1973 г. Виктор Калнин был председателем Эстонского научного общества историков медицины и членом правления Всесоюзного общества; в 1990 г. он был избран сопредседателем Балтийской ассоциации историков медицины. С 1971 г. входил в состав редколлегии советской Большой медицинской энциклопедии, внес также весьма ощутимый вклад в эстонскую энциклопедическую литературу.

Успехи научной деятельности Виктора Калнина, помимо другого, отмечены медалью К. Э. фон Бэра в 1976 г., а в 1988 г. - наградой им. П. Страдыня.

Добрые и плодотворные отношения с латвийскими коллегами у Виктора Калнина сложились уже в пятидесятые годы. Ежегодно он приезжал в Ригу, часто выступал на заседаниях Латвийского научного общества историков медицины и др. мероприятиях, неоднократно был инициатором совместных исследований, своей деятельностью способствовал развитию Музею истории медицины им. П. Страдыня. В Латвии он получил заслуженный авторитет талантливого и добросовестного исследователя, неутомимого труженика. Из жизни ушел добрый и отзывчивый человек, чей светлый образ останется в памяти всех, кто его знал.

\author{
К. Арон, А. Виксна, А. Милтиньш
}


